\title{
Employee Assistance Program as the Supporting System of Quality of Work Life to Cope with Occupational Stress
}

\author{
L. Verina Halim Secapramana, Satryo Anggoro, V. Heru Hariyanto \\ Master of Professional Psychology Education Program \\ Faculty of Psychology, University of Surabaya \\ verina@staff.ubaya.ac.id
}

\begin{abstract}
Increasing productivity has always been an important issue in the context of management. Efforts in this direction are often demands that cause occupational stress, so that a counterproductive situation may occur. Quality of Work Life (QWL) is one of the hot issues that arise to neutralize stressful conditions by creating a more comfortable and more humane working climate. The Employee Assistance Program (EAP) as an intervention can be expected to function as a supporting system. The assessment was conducted for 67 employees. The questionnaire, interview, FGD, and SWOT analysis methods are used in all three stages, the pre-assessment stage, the assessment stage, and the intervention stage. From the Occupational Inventory Stress-Revised (Osipow, 1998), there are four most significant stressor areas and personal resources that are underutilized in managing stressors. The intervention program is directed at curative and preventive services through the EAP design.
\end{abstract}

Keywords: Employee Assistance Program (EAP), Quality of Work Life (QWL), Occupational stress, supporting system

Received 5 November 2019/Accepted I5 May 2020 CJEHCP All rights reserved

\section{Introduction}

Thought to increase productivity through human resources first appeared in the early 19th century through the Scientific Management Theory by F.W. Taylor (Taylor, 1974). Since then various studies have been conducted to study human behavior in work contexts and ways to increase their job satisfaction. Quality of work life discusses all resources in the organization aimed at meeting employee job satisfaction and increasing organizational effectiveness. This concept has a variety of different meanings depending on the perspective of each person. Some people see it as a concept of democracy in the industrial world, while others see it as an increase in the psychological aspects of work to increase productivity. A more comprehensive view then concludes that QWL is a change from the overall 


\section{Journal of Educational, Health and Community Psychology Vol 9, No 2, 2020 E-ISSN 2460-8467 \\ Secapramana \\ Anggoro \\ Hariyanto}

organizational climate by humanizing the world of work, individualization of the organization and the development of structural and managerial systems (Shodhganga, 2016).

Simultaneously with the expansion of the concept, various ideas emerged regarding aspects of the QWL. Basically, this concept covers aspects of a safe work environment, guarantees of occupational health, reasonable working time, and a fair and appropriate income. In this study the concept of the European Foundation for the Improvement of Living and Working Conditions is used (EWON, 2002), which states that there are 5 (five) aspects related to quality of work life namely health and well-being, job security, job satisfaction, competency development, and work and non-work life balance (Rethinam \& Ismail, 2008). The application of the QWL concept is also a good indicator to attract attention and nurture its employees (Kanten \& Sadullah, 2012). Companies will be seen as able to provide a decent work environment through a quality work life program offered. PT $X$ is currently implementing a change program in order to support the performance of its employees to achieve the company's vision, as shown in the chart below.

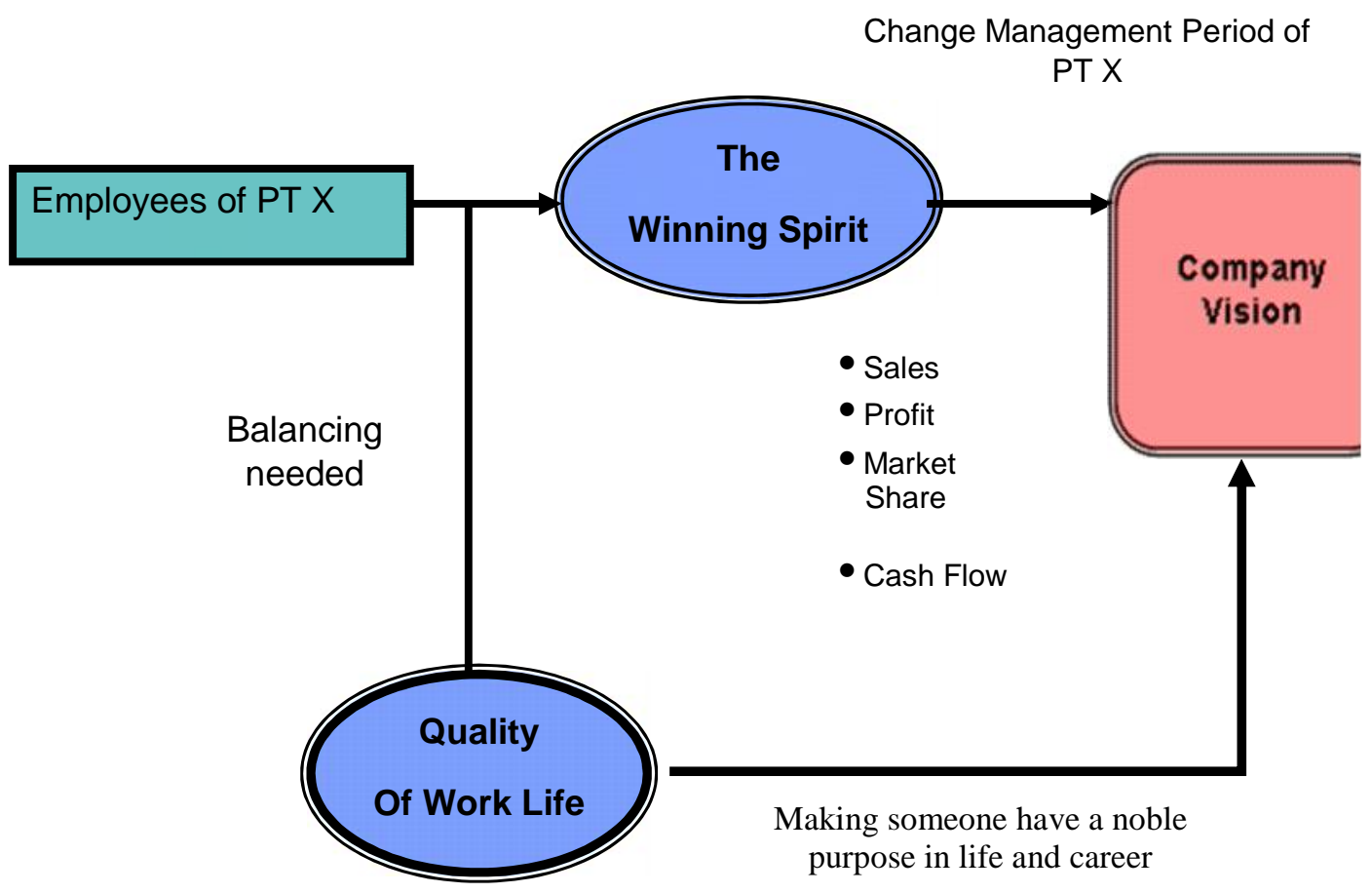

Source: Presentation by the Directors of PT. X at the company's annual meeting on April 142014 at Utami Hotel - Juanda.

Chart I. Change Process of PT X. 
The company realized that its success will be largely determined by the quality of its employees as assets that need to be maintained and managed continuously. Employees who are able to work optimally will have good quality performance and bring it to success. Personal success in the employee does not only apply to himself but will also have an impact on organizational success (Ng, 2005 in Li \& Yeo, 2012). According to Hassan et al.,(2017) QWL for staff at Malaysian automotive industry has a positive, large and significance relationship with employee loyalty.

The demand to have optimal performance can lead to psychological demands on employees. These demands increase psychological pressure which can reduce the ability of employees to control their conditions and abilities (Karasek \& Theorell, 1990). The decrease in selfcontrol will further impact on employee productivity. This condition is known as the occupational stress. Demands basically refer to psychological pressure, both quantitatively as time and speed in completing tasks, and qualitatively, for example conflicts between various contradictory demands. The stressor itself can come from various sources, such as from the environment, work, or from yourself.

The following research will measure the QWL conditions and occupational stress in the company, and then offer EAP as a supporting system to apply the Quality of Work Life concept in PT $X$. Since the condition is uniquely happened in the company, so the EAP designed is also a tailor made program.

\section{Method}

This research uses the Action Research approach. Arnold, Cooper, and Robertson (2004, referring to Lewin, 1946) used the term action research to describe research in which researchers and research subjects jointly participated. Action research is intended not only to solve problems faced by research subjects, but also to increase knowledge about the topic being studied. This approach is a "learning by doing" approach that allows a person or group to identify problems, take actions related to problem solving and see the extent of the success of these actions (O'Brien, 1998). 


\section{Participants}

Research participants are 67 employees from the executive level to the management level at the head office.

\section{Design}

This research was carried out through three stages, namely pre-assessment, assessment, and intervention. The pre-assessment stage is carried out by filling out a questionnaire to get an overview of the QWL conditions in the company. At the assessment stage interviews and Focused Group Discussion methods are carried out to explore the findings in the preassessment. This FGD was carried out by presenting several employees at each level of position to discuss with the guide questions given by researchers. Interview and FGD data will be processed to see the internal and external conditions of employees related to the dimensions mentioned above, Internal (strengths \& weaknesses) and External (opportunities \& threats) and processed into a SWOT Matrix that will produce several strategic choices.

\section{Questionnaires}

Data to obtain overview of occupational stress using the adaptation questionnaire instrument from the Occupational Stress Inventory-Revised/OSI_R (Osipow, 1998). The data is supplemented with data from the stressor instrument to identify areas that still need attention and what stressors play a role in influencing employees. Data will be processed through statistical tests to see areas of stressors that still need attention.

The next data collection is through the Occupational Stress Inventory-Revised/OSI_R instrument (Osipow, 1998). The Occupational Stress inventory is a brief measurement of three dimensions: stress related to employees, psychological tension, and sources of resolution. The three dimensions are Occupational Roles Questionnaire (ORQ), Personal Strain Questionnaire (PSQ), and Personal Resources Questionnaire (PRQ). On the ORQ and PSQ dimensions, the higher the value indicates the more significant stress related to employees, and psychological tension felt by employees. On the PRQ scale, the higher the value the more it indicates that a person has developed his personal quality in dealing with stress. 
Table I

OSI-R aspects and measured by each aspect

\begin{tabular}{ll}
\hline Scale/Aspek & What Each Scale Measures \\
\hline $\begin{array}{l}\text { Occupational Roles Questionnaire (ORQ) } \\
\text { Role Overload }\end{array}$ & $\begin{array}{l}\text { Job demands, resources, and the ability to complete tasks } \\
\text { Role Insufficiency }\end{array}$ \\
$\begin{array}{l}\text { Suitability between employee and ability, the need for } \\
\text { recognition, boredom }\end{array}$ \\
Awareness of one's expectations \\
Role Boundary & The level of conflict between loyalty and priority in the work \\
& environment \\
Role Responsibility & Feelings of responsibility for the welfare and performance of \\
& others \\
Physical Environment & Exposure to stress due to work environment (e.g., sound heat, \\
Personal Strain Questionnaire (PSQ) & Attitudes towards employment, problems in the quality / quantity \\
Vocational Strain & of work \\
Psychological Strain & Having psychological problems \\
Interpersonal Strain & The degree of interruption in interpersonal relations \\
Physical Strain & Symptoms of physical pain and concern about health \\
Personal Resources Questionnaire (PRQ) \\
Recreation & Level of involvement in leisure activities \\
Self-Care & Self-participation in reduces stress habits \\
Social Support & The feeling of having social support and help from others \\
Rational/Cognitive Coping & Knowledge and use of cognitive techniques to deal with stress \\
\hline
\end{tabular}

Table 2

Validity and Reliability

\begin{tabular}{ccc}
\hline \multicolumn{3}{c}{ Occuptional Roles Questionaire (ORQ) } \\
\hline Role Overload & Reliability Index & Validity Range \\
Role Insuffiency & 0,586 & $0.139-0.566$ \\
Role Ambiguity & 0.606 & $0.132-0.586$ \\
Role Boundary & 0.792 & $0.123-0.791$ \\
Role Responsibility & 0.542 & $0.247-0.430$ \\
Physical Environment & 0.554 & $0.169-0.462$ \\
\hline
\end{tabular}




\begin{tabular}{|c|c|c|}
\hline \multicolumn{3}{|c|}{ Personal Strain Questionaire (PSQ) } \\
\hline & $\begin{array}{l}\text { Reliability } \\
\text { Index }\end{array}$ & $\begin{array}{l}\text { Validity } \\
\text { Range }\end{array}$ \\
\hline Vocational Strain & 0.637 & 0.472 \\
\hline Psychological Strain & 0.710 & $0.115-0.718$ \\
\hline Interpersonal Strain & 0.506 & $0.149-0.515$ \\
\hline Physical Strain & 0.669 & $0.295-0.593$ \\
\hline \multicolumn{3}{|c|}{ Personal Resorces Questionaire (PRQ) } \\
\hline & $\begin{array}{l}\text { Reliability } \\
\text { Index }\end{array}$ & $\begin{array}{l}\text { Validity } \\
\text { Range }\end{array}$ \\
\hline Recreation & 0.582 & $\begin{array}{c}0.123- \\
0.576\end{array}$ \\
\hline Self Care & 0.532 & $\begin{array}{c}0.222- \\
0.373\end{array}$ \\
\hline Social Support & 0.825 & $\begin{array}{c}0.501- \\
0.724\end{array}$ \\
\hline $\begin{array}{c}\text { Rational/Cognitive } \\
\text { Coping }\end{array}$ & 0.717 & $\begin{array}{c}0.174- \\
0.647\end{array}$ \\
\hline
\end{tabular}

An overview of the research stages can be seen through the chart below.

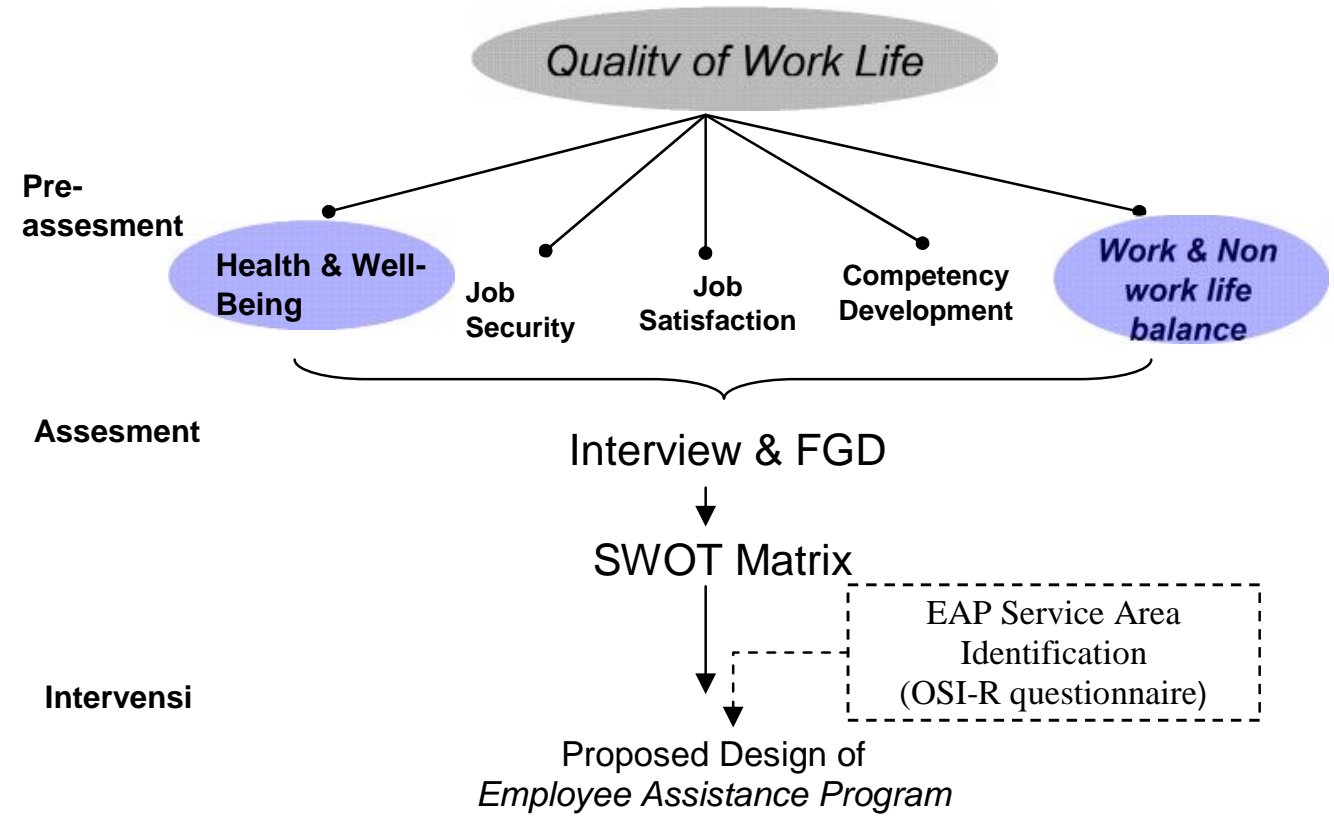

Chart 2. Research Stages 


\section{Result}

Pre-assessment Stage

The pre-assessment results show that there are three dimensions that require attention. From the results below, it can be seen that there are 3 dimensions which are classified as not good (total value <70), namely the dimensions of Health \& Well Being, the Job Satisfaction dimension, and the Work \& Non-work Life Balance dimension. These results indicate that the need for a healthy and prosperous environment, job satisfaction and balance between work and outside employees are not met in the company

Table 3

Pre-assessment QWL category results per dimension on the employees of PT. $X$

\begin{tabular}{|c|c|c|c|c|c|c|c|c|c|c|}
\hline & \multicolumn{2}{|c|}{ Health \& Well Being } & \multicolumn{2}{|c|}{ Job Security } & \multicolumn{2}{|c|}{$\begin{array}{l}\text { Job } \\
\text { Satisfaction }\end{array}$} & \multicolumn{2}{|c|}{$\begin{array}{l}\text { Competency } \\
\text { Development }\end{array}$} & \multicolumn{2}{|c|}{$\begin{array}{l}\text { Work } 8 \\
\text { Non-work } \\
\text { Life Balance }\end{array}$} \\
\hline & Frequency & $\%$ & Frqc & $\%$ & Frqc & $\%$ & Frqc & $\%$ & Frqc & $\%$ \\
\hline Very High & 15 & 13.04 & 31 & 26.96 & 24 & 20.87 & 93 & 80.87 & 23 & 20 \\
\hline High & 33 & 28.7 & 47 & 40.87 & 18 & 15.65 & 16 & 13.91 & 18 & 15.65 \\
\hline Moderate & 29 & 25.22 & 32 & 27.83 & 29 & 25.22 & 2 & 1.74 & 32 & 27.83 \\
\hline Low & 25 & 21.74 & I & 0.87 & 25 & 21.74 & 3 & 2.61 & 19 & 16.52 \\
\hline Very Low & 13 & 11.3 & 4 & 3.48 & 19 & 16.52 & I & 0.87 & 23 & 20 \\
\hline $\begin{array}{l}\text { Total } \\
\text { Total QWL Value } \\
\text { per Dimension }\end{array}$ & 62.08696 & 100 & 115 & 100 & 115 & 100 & 115 & 100 & 115 & 100 \\
\hline
\end{tabular}

Based on discussions with PT. $X$, the agreed aspects for intervention are on the dimensions of Health \& Well-being and Work \& Non-Work Life Balance. The consideration is that the Job Satisfaction dimension has to do with aspects of salary and other things such as bonuses given by the company to employees, while at this time the company is developing a performance appraisal program that is expected to be fair to see employee performance and become the basis for bonuses or rewards and benefits. the other.

\section{Assessment Phase}

Analysis of interview and FGD data through SWOT Matrix

From the data it is obtained strategic areas in the form of SO (Strength - Opprotunity), ST (Strength - Threat), WO (Weakness - Opportunity), and WT (Weakness - Threat). SO 
Strategy is a strategy that is carried out by utilizing strengths and opportunities, ST Strategy is a strategy that utilizes strengths to overcome threats / obstacles, WO Strategy is a strategy that utilizes opportunities to overcome weaknesses, and WT Strategy is a choice of possible strategies to overcome both. The following are the results of a collection of strategies that emerged:

I. There is a company policy to support social activities outside employees.

2. Regular training on improving hard skills or soft skills.

3. Sharing group of employees after training

4. The existence of EAP (Employee Assistance Program) as a companion media for employees in helping them when they have problems in the field of employee or personal.

5. There is a communication forum between the company and the family (gathering)

6. Investment of technology.

7. Internal resource development: focusing on the formation of work ethics and professionalism, communication and interpersonal skills, as well as performance and competency assessment systems.

8. Increasing the variety of physical facilities to support convenient climate at work

Results from Occupational Stress Inventory-Revised I OSI-R (Osipow, 1998)

In the table below, there are four aspects that require attention from the company, namely, role insuffiency $(62.7 \%)$, role ambiguity $(49.3 \%)$, role boundary $(37.3 \%)$ and vocational strain (64.2\%). 
Table 4

Stressor Aspect Table

\begin{tabular}{|c|c|c|c|c|c|c|}
\hline \multirow{2}{*}{ Dimension } & \multirow{2}{*}{ Aspect } & \multicolumn{2}{|c|}{$\begin{array}{l}\text { Number of samples } \\
\text { that require } \\
\text { attention }\end{array}$} & \multicolumn{2}{|c|}{$\begin{array}{l}\text { Number of samples that } \\
\text { don't require attention }\end{array}$} & \multirow{2}{*}{$\begin{array}{l}\text { Total } \\
\mathrm{N}\end{array}$} \\
\hline & & $\begin{array}{l}\text { Frequen } \\
\text { cy }\end{array}$ & Percent & Frequency & Percent & \\
\hline \multirow{6}{*}{$\begin{array}{l}\text { Occupational } \\
\text { Role } \\
\text { Questionnaire }\end{array}$} & Role Overload & II & $16.4 \%$ & 56 & $83.6 \%$ & 67 \\
\hline & Role Insuffiency & 42 & $62.7 \%$ & 25 & $37.3 \%$ & 67 \\
\hline & Role Ambiguity & 33 & $49.3 \%$ & 34 & $50.7 \%$ & 67 \\
\hline & Role Boundary & 25 & $37.3 \%$ & 42 & $62.7 \%$ & 67 \\
\hline & Role Responsibility & 14 & $20.9 \%$ & 53 & $79.1 \%$ & 67 \\
\hline & $\begin{array}{l}\text { Physical } \\
\text { Environment }\end{array}$ & II & $16.4 \%$ & 56 & $83.6 \%$ & 67 \\
\hline \multirow{4}{*}{$\begin{array}{l}\text { Personal } \\
\text { Strain } \\
\text { Questionnaire }\end{array}$} & Vocational Strain & 43 & $64.2 \%$ & 24 & $35.8 \%$ & 67 \\
\hline & Psychological Strain & 7 & $10.4 \%$ & 60 & $89.6 \%$ & 67 \\
\hline & Interpersonal Strain & 8 & $11.9 \%$ & 59 & $88.1 \%$ & 67 \\
\hline & Physical Strain & 7 & $10.4 \%$ & 60 & $89.6 \%$ & 67 \\
\hline
\end{tabular}

Table 5

Table of Aspects of Personal Resources

\begin{tabular}{|c|c|c|c|c|c|}
\hline \multirow[t]{2}{*}{ Aspects } & \multicolumn{2}{|c|}{$\begin{array}{l}\text { Number of samples } \\
\text { that require attention }\end{array}$} & \multicolumn{2}{|c|}{$\begin{array}{l}\text { Number of samples that } \\
\text { doesn't require } \\
\text { attention }\end{array}$} & \multirow{2}{*}{$\begin{array}{l}\text { Tota } \\
\mathrm{N}\end{array}$} \\
\hline & Frequency & Percent & Frequency & Percent & \\
\hline Recreation & 33 & $49.3 \%$ & 34 & $50.7 \%$ & 67 \\
\hline Self Care & 46 & $68.7 \%$ & 21 & $31.3 \%$ & 67 \\
\hline Social Support & 22 & $32.8 \%$ & 45 & $67.2 \%$ & 67 \\
\hline $\begin{array}{l}\text { Rational/Cognitive } \\
\text { Coping }\end{array}$ & 23 & $34.3 \%$ & 44 & $65.7 \%$ & 67 \\
\hline
\end{tabular}

Personal Resources allows someone to be able to do their own ways in resolving or alleviating stress. The numbers of samples that require attention to the dimensions of Personal Resources include all aspects, namely recreation $49.3 \%$, self care $68.7 \%$, social support $32.8 \%$ and rational / cognitive coping at 34.4\%. In this Personal Resources dimension, it is found that all aspects are felt to be lacking or need to be a concern for many employees. This indicates that many employees still lack good self-ability in treating stress. Most employees need strengthening themselves in all four aspects as a preventive measure against stress that arises from time to time for every employee. 
By comparing data from interviews and FGDs, an overview can be obtained about the possible causes of stress and estimating the likelihood that stressors are widespread in employees. The data can be seen in the table below:

Personal or individual factors as vulnerability to experiencing stress

The role of personal resources is tried to be seen by conducting a regression analysis to see the possible aspects of personal resources (Recreation, Self Care, Social Support, Rational / Cognitive Coping) as a predictor of the emergence of stress in other dimensions and in particular other aspects. The analysis test performs a regression test by looking at the significance value in the ANOVA table below or equal to $(\leq) 0.05$. A brief result will be explained as follows.

In the Occupational Role dimension, aspects of personal resources significantly contribute $15.7 \%$ as a predictor of the emergence of stressors. In the Personal Strain Dimension, aspects of personal resources significantly contribute to $18.2 \%$ as a predictor of the emergence of stressors in this area. Furthermore, the researcher tries to explore the possibility of the four aspects of personal resources being a predictor of each aspect of the two dimensions. The results are known that aspects of personal resources are able to predict the emergence of stressors in several aspects, namely Role Ambiguity of 17.4\%, Role responsibility of $20.9 \%$, Physical Environment of $35.5 \%$, Interpersonal Strain of $27.8 \%$, and Physical Strain of $44.8 \%$. Researchers explore more about how big the role of each aspect of Personal Resouces towards each aspect of the stressor. 


\section{Journal of Educational, Health and Community Psychology Secapramana Vol 9, No 2, 2020 E-ISSN 2460-8467 Anggoro \\ Hariyanto}

Table 6

Table of Problem Areas and Empirical Data

\begin{tabular}{|c|c|c|}
\hline Aspect & Item & Organizational Factor \\
\hline $\begin{array}{l}\text { Vocational } \\
\text { Strain }\end{array}$ & $\begin{array}{l}\text { I. See employees as something that is less } \\
\text { interesting or less exciting } \\
\text { 2. Less able to concentrate on what is } \\
\text { needed when working }\end{array}$ & $\begin{array}{l}\text { I. Fairness in terms of distributing } \\
\text { bonuses, implementing rules, } \\
\text { recruiting and promoting } \\
\text { employees. } \\
\text { 2. Boredom at work }\end{array}$ \\
\hline $\begin{array}{l}\text { Role } \\
\text { Insuffiency }\end{array}$ & $\begin{array}{l}\text { 2. Careers did not improve as expected } \\
\text { 3. Not able to meet the needs for success and } \\
\text { be valued at work. } \\
\text { 4. Employees lack a good future (career }\end{array}$ & $\begin{array}{l}\text { I. Unequal recruitment system. } \\
\text { 2. Labor-intensive employees } \\
\text { 3. Rolling position is minimal } \\
\text { 4. Minimum promotion } \\
\text { opportunities }\end{array}$ \\
\hline \multirow[t]{5}{*}{$\begin{array}{l}\text { Role } \\
\text { Ambiguity }\end{array}$} & $\begin{array}{l}\text { I.Understand clearly what needs to be done } \\
\text { in the employee }\end{array}$ & $\begin{array}{l}\text { I. Clear parameters regarding } \\
\text { performance appraisal. }\end{array}$ \\
\hline & $\begin{array}{l}\text { 2.Know what are the basics of work } \\
\text { assessment } \\
\text { 3. The boss asks to do one thing, but actually } \\
\text { has another intention }\end{array}$ & $\begin{array}{l}\text { 2. The attitude of influence } \\
\text { negatively affects the } \\
\text { formation of professionalism in } \\
\text { employees and management. }\end{array}$ \\
\hline & $\begin{array}{l}\text { 5. Know where to start when asked to } \\
\text { handle a project }\end{array}$ & $\begin{array}{l}\text { 3.The existence of ABS culture } \\
\text { (Originally, I'm Happy) }\end{array}$ \\
\hline & $\begin{array}{l}\text { 6. Clearly understand the priorities in the } \\
\text { employee }\end{array}$ & $\begin{array}{l}\text { 4. Employees who are resistant to } \\
\text { change, making it difficult to } \\
\text { adjust to the new company } \\
\text { systems and policies }\end{array}$ \\
\hline & $\begin{array}{l}\text { 7. Bosses provide useful input regarding } \\
\text { performance }\end{array}$ & \\
\hline $\begin{array}{l}\text { Role } \\
\text { Boundary }\end{array}$ & $\begin{array}{l}\text { 1. There is a contradiction in feelings } \\
\text { between what the boss expects to do } \\
\text { with what is thought to be true or } \\
\text { appropriate } \\
\text { 2. there is more than one person giving the } \\
\text { Order } \\
\text { 3.Sometimes there are disagreements with } \\
\text { people from other units or departments }\end{array}$ & $\begin{array}{l}\text { 1.Guyub attitude affects } \\
\text { negatively the formation of } \\
\text { professionalism in themselves } \\
\text { 2. Employees who ignore work } \\
\text { processes should and make } \\
\text { contact with other parts of the } \\
\text { work process. This causes } \\
\text { conflicts between employees } \\
\text { between divisions. } \\
\text { 3. There is disharmony among } \\
\text { some employees that affects } \\
\text { work style }\end{array}$ \\
\hline
\end{tabular}


Table 7

Table of Effective Donations of Personal Resources on Stressor Areas that need attention

\begin{tabular}{llllll}
\hline & $\begin{array}{l}\text { Role } \\
\text { ambiguity }\end{array}$ & $\begin{array}{l}\text { Role } \\
\text { Responsibility }\end{array}$ & $\begin{array}{l}\text { Physical } \\
\text { Environment }\end{array}$ & $\begin{array}{l}\text { Interpersonal } \\
\text { Strain }\end{array}$ & $\begin{array}{l}\text { Physical } \\
\text { Strain }\end{array}$ \\
\hline Effective & Effective & Effective & Effective & Effective & Effective \\
Contribution & Contributio & $\begin{array}{l}\text { Contribution } \\
\text { Contribution }\end{array}$ & Contribution & Contributio \\
Recreation & $\mathrm{n}$ & 4.97 & 8.00 & 2.16 & $\mathrm{n}$ \\
Self Care & 5.88 & 3.68 & 4.16 & 7.11 & 5.13 \\
Social Support & 0.66 & 3.66 & 10.51 & 7.75 & 11.30 \\
$\begin{array}{l}\text { Rational/Cognitive } \\
\text { Coping }\end{array}$ & 4.17 & 8.32 & 12.83 & 10.78 & 1.39 \\
\hline
\end{tabular}

From the table above can be explained as follows :

Ambiguity Role

The aspects of personal resources significantly contribute to $17.4 \%$ as a predictor of the emergence of stressors in this area. Furthermore, sequentially from the most influential to the least influential, from $17.4 \%$ the Social Support aspect had an effect of $6.66 \%$, the Recreation aspect had an effect of 5.88\%, and the Rational / Cognitive Coping aspect had an effect of $4.17 \%$ on the Role Ambiguity aspect.

Role Responsibility

The aspects of personal resources significantly contribute to $20.9 \%$ as a predictor of the emergence of stressors in this area. Furthermore, sequentially from the most influential to the least influential, from $20.9 \%$ the Rational / Cognitive Coping aspect had an effect of $8.32 \%$, the Recreation aspect had an effect of $4.97 \%$, the Social Support aspect had an effect of $3.93 \%$, and the Self Care aspect had an effect of $3.68 \%$ on aspects of Role Responsibility.

\section{Physical Environment}

The aspects of personal resources significantly contribute to $35.5 \%$ as a predictor of the emergence of stressors in this area. Furthermore, sequentially from the most influential to the least influential, from $35.5 \%$ the Rational / Cognitive Coping aspect had an effect of $12.83 \%$, the Social Support aspect had an effect of $10.51 \%$, the Recreation aspect had an effect of $8 \%$, and the Self Care aspect had an effect of $4.16 \%$ aspects of the Physical Environment. 
Interpersonal Strain

The aspects of personal resources significantly contribute to $27.8 \%$ as a predictor of the emergence of stressors in this area. Furthermore, sequentially from the most influential to the least influential, from 27.8\%, the Rational / Cognitive Coping aspect has an effect of 10.78\%, the Social Support aspect has an effect of $7.75 \%$, the Self Care aspect has an effect of $7.11 \%$, and the Recreation aspect has an effect of $2.16 \%$ on aspects of Interpersonal Strain.

\section{Physical Strain}

The aspects of personal resources significantly contribute to $20 \%$ as a predictor of the emergence of stressors in this area. Furthermore, sequentially from the most influential to the least influential, from the $20 \%$ the Self Care aspect had an effect of $11.3 \%$, the Recreation aspect had an effect of $5.13 \%$, the Social Support aspect had an effect of $2.18 \%$, and the Rational / Cognitive Coping aspect had an effect of $1.39 \%$ on aspects of Physical Strain.

\section{Discussion}

The above data shows that aspects of personal resources are able to predict significantly the emergence of stress in two dimensions, namely the Occupational Roles dimension and the Personal Strain dimension. This prediction shows that a person's lack of ability to solve problems will affect the area of his work life. This indicates that the resources within themselves have an important role for an employee in managing stress, in addition to other factors. Many employees still lack good self-ability in treating stress.

Organizational factors show that there are areas that need attention that is curative because problems in these areas have occurred long enough so that they require treatment. Data on personal factors shows that employees need self-reinforcement in treating the stress experienced. Therefore, the proposed intervention is a program that leads to curative and preventive actions against stress that arise at any time on each employee. 
Intervention Stage

If you look at the results of the SWOT MATRIX strategy and the results of the Occupational Stress Inventory measurement data above, the proposed interventions that include curative or preventive action are at the point of making EAP as employee companion media in assisting them when they have problems in the field of employee or personal. As you know above, it is very important to have personal qualities that are able to have ways to manage the stresses that arise.Therefore the proposed interventions are as follows:

Plan for the stages of EAP design

Identification of Problems: work relationships with colleagues or superiors, career, or personal problems. This is done to determine the direction of service (eg Counseling, Stress Management, Training \& Development in terms of improving personal quality, etc.). This stage has been carried out through the Stress Instrument (Occupational Stress Inventory).

Through measurement, the results show that there are some important areas that need to be of concern to the company. these areas are corridors for companies to determine the direction of EAP services. These areas are Role Insuffiency, Role Ambiguity, Role Boundary, Vocational Strain. These four aspects are stressor areas that occupy the highest place in their effective contribution to stress formation. The first three aspects are areas of workrelated problems and Vocational Strains are areas of one's attitude towards employees (attitude toward work) which contribute to causing stress in most of the majority of the sample. In addition, there are four personal areas that also become weaknesses: Recreation, Self Care, Social Support, and Rational / Cognitive Coping. The four areas are areas of personal resources in dealing with stressors that occur. Service directions that can be applied try to cover both curative and preventive characteristics. Curative can be in the form of coaching or counseling, behavioral therapy, or other forms of intervention needed according to client / employee problems. Preventive can be in the form of training and development, education to employees, seminars on self-reinforcement that can be done to minimize stress and its impact. 
Determine the service delivery system (eg counselor roles \& responsibilities, applicable codes of ethics, etc.). This is done as a guide or standard for providing EAP services in the company. The form of this stage is to provide an outline of things that need attention by the company in establishing service procedures.

EAP Promotion Media. This EAP program will run smoothly if fully supported by top management and ongoing program and education promotion.

\section{Conclusions}

Inequality in the workload received makes employees more uncomfortable at work. One of the interviewees said that the excessive workload made him less time to gather with family, relatives outside the office and conduct joint activities. He said that he had fallen ill due to overwork. The workload can cause stress and decreased health. He felt a conflict of interest, so that one life must be sacrificed.

From the analysis of stress instrument data, the results obtained in the form of areas that need to be considered by the company, namely the area of Role insuffiency, role ambiguity, role boundary, vocational strains. These four aspects are stressor areas that occupy the highest place in their effective contribution to stress formation. The first three aspects are areas of work-related problems and Vocational Strains are areas of one's attitude towards employees (attitude toward work) which contribute to causing stress in most of the majority of the sample.

In addition, there are four personal areas that also become weaknesses: recreation, self care, social support, and rational / cognitive coping. The four areas are areas of personal resources in dealing with stressors that occur. Supposedly, the four areas were used as selftreatment against stressors that occur, but the data shows that this area of personal resources is also not very good.

The researcher concludes that the area of work-related problems, one's attitude to employees, and personal resources are areas that need to be addressed by the company. 
Researchers see that the treatment needed can be curative or preventive. First, curative because researchers see that work-related problems and attitudes towards employees are a result of a long-standing and influential work culture in the company, interventions for these problems are certainly remedial and addressing existing or existing problems. Second, preventive because researchers see that strengthening of personal resources will be able to become an early intervention or filter of symptoms that arise. Education about self empowerment will also help preventive measures for employees to prevent widespread stress and affect performance and other aspects of life. Therefore, the researcher proposes a program that is able globally to cover this curative and preventive nature through the proposed procurement of the Employee Assistance Program.

The researcher has mapped the problem as an initial identification of EAP service development. The problem areas above will be input for companies regarding the direction of services provided by the Employee Assistance program. Furthermore, the researcher developed standards and guidelines that have been adapted from the EAPA Standard and Professional Guidelines for Employee Assistance Program. The researcher also gives an example of a product from one of the elements in the standards and professional guidelines, namely promotional material about EAP services that can be adapted by the company, if the company will actually implement this later.

\section{Possible Constraints in Implementing the Intervention Design}

The implementation of the following EAP service intervention design may not be without obstacles. Researchers see several things that allow this service to not run optimally, namely:

\section{Management Involvement}

Management needs to ensure that the chain of command is understood, impregnated, and carried out from the executive level to the lowest level. The involvement shown by management will make employees at the lower level see that management is serious and takes care of their employees. This involvement will create a message that this service is important and encourage employees to get involved in this EAP service. 
The possibility of stigma from employees who might consider employees "sick" are if they visit EAP services. In addition, another stigma that may emerge is that they will be assessed and will affect the performance appraisal or the continuation of their work in the company. This will certainly cause reluctance from employees to enjoy EAP services. Of course, this can be overcome with the ongoing program of socialization and promotion as education and awareness to employees about the credibility, the confidentiality of services, and the benefits obtained when receiving EAP services. The ability of leaders to identify problem employees are important. There needs to be a session for managerial level leaders (supervisors and above) to understand the basic abilities of coaching and counselling. This capability is the first filter that is able to identify problem employees before finally being referred to the EAP service.

\section{Suggestions}

There are several things that are of concern to researchers. If this research is continued, the next researcher needs to ensure the active involvement of the stake holders, from the executive level to the executive level. Researchers need to ensure that executive directives regarding engagement are truly understood and implemented to the lowest level. Involvement at all of these levels will make it easier for researchers to collect data, process data, and arrange designs or intervention programs without missing data. The draft Employee Assistance Program is only in the form of a proposal for companies to implement this program. The researcher includes also the basic elements that need to be in EAP implementation. If this research is continued, it would be better if these important elements are reacted back to detailed results to be able to be directly applied by the company. This implies the involvement of both parties, researchers and stakeholders to jointly compile the details of the preparation for the implementation of the Employee Assistance Program in companies where further research is conducted later.

\section{References}

Azzone, V. (2009). Workplace stress, organizational factors and EAP utilization. Journal of Workplace Behavioral Health, 24, 344-356. 
Arifin, N. (20/2). Analisis kualitas kehidupan kerja, kinerja, dan kepuasan kerja pada CV. Duta Senenan Jepara. Jurnal Economia, 8(I), 45-59.

Amin, Z. (2013). Quality of work life in indonesian public service organizations: The role of career development and personal factors. International Journal of Applied Psychology, 3(3): 38-44. doi: 10.5923/j.ijap.20130303.02.

Bassam A-Daibat. (2018) a study on quality of work life (QWL) in Jordanian Universities. International Journal of Business and Management Review, 6(II), 66-74.

Bophela, N. R., \& Govender, P. (2015). Employee assistance programs (EAPs): Tools for quality of work life. Problems and Perspectives in Management, 13(2), 236-248.

Cascio, W. F., \& Boudreau, J. W. (20I I). Investing in people: Financial impact of human resource initiatives. $2^{\text {nd }}$ ed. Pearson FT Press.

Cooper, Cary L. \& Ivan T. Robertson.2004. Work psychology : Understanding human behaviour in the workplace . $4^{\text {th }}$ ed. Prentice Hall.

EAP Workgroup (2008). An employer's guide to employee assistance programs: recommendations for strategically defining, integrating, and measuring employee assistance programs. The National Business Group on Health. Retrieved from : http://www.easna.org/documents/PS2NBGRecommendationsforDefiningandMeasuring EAPs.pdf

EAPA (20I0). EAPA standards and professional guidelines for employee asisstance programs. Retrieved from : http://www.eapassn.org/Portals/ I /Docs/EAPAStandards I0.pdf

Employee Assistance Programs - Philosophy, theory and practice. (1986). Royal Canadian mounted police external review committee.

Hassan, N., Zahidi, N A., Aziz, R., Razak, N., Hamid, N. Z., \& Halif, M. (20I7). Quality of work life as a predictor toward employee loyalty at malaysian automotive industry. International Journal of Arts \& Sciences, IO(I) 23-35.

Holosko, M. J. \& Feit, M. D. (1988). Evaluation of employee assistance programs. New York: The Haworth Press.

Kanten, S \& Sadullah, O. (20I2). An empirical research on relationship quality of work life and work engagement. Procedia - Social and Behavioral Sciences, 62, 360 - 366.

Karasek, R., \& Theorell, T. (1990). Healthy work: Stress, productivity, and the reconstruction of working life . New York: Basic Books.

Lawler, F. 1982. Strategies for improving the quality of work life. American Psychologist. 37, 486-49.

Li, J., \& Yeo, R. K. (20I I). Quality of work life and career development: Perceptions of part time MBA students. Employee Relations, 33(3), 20I-220. doi: I0.II08/0I42545IIIIII2I740.

Li, J., \& Yeo, R. K. (20I3). In pursuit of learning: Sense making the quality of work life. European Journal of Training and Development, 37(2), 136-160. doi: 10.1108/030905913 II301662. 
Martel, J.-P., \& Dupuis, G. (2006). Quality of work life: Theoretical and methodological problems, and presentation of a new model and measuring instrument. Social Indicators Research, 77(2), 333-368. doi: 10.1007/s I |205-004-5368-4.

Merrick,.L., et al. (2007). Revisiting employee assistance programs and substance use problems in the workplace: Key issues and a research agenda. Psychiatric Services, 58(10), 67-79.

Munandar, A. S., Sjabadhyni, B., \& Wuturq R. P. (2004). Peran budaya qrganisasi dalam peningkatan unjuk kerja perusahaan depok. Bagian Psikologi Industri \& Organisasi, Fakultas Psikologi Universitas Indonesia.

O'brien, Roy. (1998) An overview of the methodological approach of action research. faculty of information studies, University of Toronto. Retrieved from: http://www.web.ca/ robrien/papers/arfinal.html

Reilly, N.P., Sirgy, M.J., Gorman, C.A. (2012). Work and quality of life: Ethical practices in organizations. NY: Springer.

Rethinam, G. S., Ismail, M. (2008). Construct of quality of work life: A prespective of information and technology professionals. European Journal of Social Sciences. 7(I), I32149.

Secapramana, L. V. H. (20I5). Employee assistance program as an intervention to improve the quality of work life. Fakultas Psikologi Universitas Surabaya.

Shodhganga (2016). Chapter I introduction to quality of work life. Retrieved from : https://shodhganga.inflibnet.ac.in/bitstream/10603/7/42I/8/08 chapter\%20I.pdf

Sirgy, M. J., Reilly, N. P., Wu, J., \& Efraty, D. (2008). A work-life identity model of well-being: towards a research agenda linking quality-of-work-life $(\mathrm{QWL})$ programs with quality of life (QOL). Applied Research in Quality of Life, 3(3), I8I-202. doi: I0.1007/s I I482-0089054-6

Sharar \& Lennox (20/4). The workplace effects of EAP Use: Pooled "results from 20 different EAPS with before and after WOS 5-Item data. EASNA Research Notes. Vol 4, No. $I$.

Steele, P. (1998). Employee assistance programs: Then, Now, and in the Future. New York: Sage Publising.

Taylor, Frederick, W. (1974). The principles of scientific management, in Scientific Management, Harper and Row, New York, Pp. 24-25.

Ventegodt, S. \& Merrick, J. (2009). Health and happiness from meaningful work: Research in quality of working life. New York: Nova Science Publisher, Inc. 